\title{
Grover 波動アルゴリズムによる空間コヒーレントな風カエネルギーの集中
}

Spatial coherent wind power concentration by using Grover wave algorithm

\author{
内田秀範・三重大工 \\ Hidenori Uchida, Mie University
}

小竹茂夫 · 三重大工

鈴木泰之・三重大工

Shigeo Kotake, Mie University

Yasuyuki Suzuki, Mie University

Key Words: Wind Power Generation, Temporal Random Wind, Quantum Algorithm

\section{1. 緒言}

地球温暖化問題の防止から, 化石然料に頼らないエネル ギ一源として風力の利用が注目されている.一方、風力は エネルギー密度が低く, 時間的変動も大きいため, 大きな 電力の発生は期待できない. できるだけ広い空間からエネ ルギーを取り出すために風車等の大型化が進んでいるが, 剛構造の羽根を必要とするため大きさには限界が存在する.

一方，空間に広がった波動を効率よく局所的な空間に集 める方法として Groverアルゴリズムが量子情報の分野で提 案された [1].コヒーレントな波動に現れるこのアルゴリズ ムは, 古典的な波動現象にも適応可能であり，これを利用 した光学 [2]や振動現象 [3]への応用が提案されている.

自然風は方向および大きさは, 時間的にはランダムだが, 空間的には広範囲に同じ傾向を持つコヒーレントな性質を 有している. そこで本研究では, Grover 波動アルゴリズム を実現する多体振動系 [4]を用いることで, 空間的にコヒー レンスを有する風力等のエネルギーを集中させることを試 み, これを利用した風力発電の可能性を考察する.

\section{Grover 波動アルゴリズムが成り立つ振動系}

Grover 波動アルゴリズムを実現する系の例として，彼本 人が提唱した多体振動系のモデルを Fig.1 に示す [1]. 質量 $m$, バネ定数 $k$ の $N$ 個の小振動子における振動が Grover 量 子アルゴリズムにおける各量子状態に相当する. ここで他 の小振動子と固有振動数が異なる質量 $m$ ', ばね定数 $k$ 'の特 殊振動子を 1 個おき、ここに発電機を設置する.

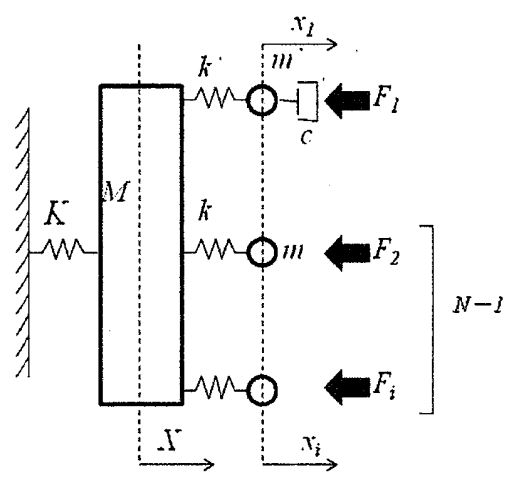

Fig. 1 減衰と外力が働く場合の多体振動系

特殊振動子に掛かる発電時の反力は速度に比例する減衰 力であり，風力は小振動子全体に掛かる外力とみなせる.
各小振動子に掛かる外力を $F_{i}(t)[\mathrm{N}]$ とした 場合, 多体振動 系の運動方程式は以下のように表される.

$$
\left\{\begin{array}{c}
M \ddot{X}+K X+k_{1}\left(X-x_{1}\right)+\sum_{i=2}^{N} k\left(X-x_{i}\right)=0 \\
m \ddot{x}_{i}+k\left(x_{i}-X\right)=F_{i}\left(t_{i}\right) \\
m^{\prime} \ddot{x}_{1}+k^{\prime}\left(x_{1}-X\right)+c \dot{x}_{1}=F_{1}\left(t_{1}\right)
\end{array}\right.
$$

ただし， $i=2 ， 3 ， \cdots N$ である. $M$ と $K$ は小振動子が繋がる 大振動子の質量とバネ定数であり, Grover アルゴリズムが 成り立つ条件

$$
\begin{aligned}
& M=\frac{16 k(N-1)}{(2 p+1)^{2}\left(4-\frac{m}{k}\right)+4-\frac{16 k}{m}} \\
& K=\frac{(2 p+1)^{2}(N-1) m}{(2 p+1)^{2}\left(4-\frac{m}{k}\right)+4-\frac{16 k}{m}}-k_{1}
\end{aligned}
$$

を用いる.これらの条件は，自然数 $p$ を増加させることに より，ロバスト性が生じ， $M$ を小さくできることから，ケ 一ブル等の軟構造の振動子でも, 実現可能となる.

\section{3. シミュレーション結果および考察}

\section{3-1 計算方法}

Fig.1 に示すモデルを用い 4 次の Runge-Kutta 法により数 值計算を行った. 特殊振動子は Grover のアルゴリズムが成 り立つよう $m^{\prime}=4, k^{\prime}=1$ とした. また, その他の $N-1$ 個の 小振動子は $m=1, k=1$ とした. 初期条件については $\dot{X}=0, \dot{x}_{1}=1, \dot{x}_{i}=1, X=0, x_{1}=0, x_{i}=0$ としたが，外力を入 れた場合，振動は初期条件には依らなかった，以下の計算 においては, 時間的にランダムな風を表現するため, 外力 の時間間隔および大きさはそれぞれ，0〜10[s]（または $\mathrm{N}]$ ) の間の乱数を用いた. 以下では, $N=300, c=0.1$ における, $t=500[\mathrm{~s}]$ 間の数值計算結果を示寸.

\section{3-2 外部入力とエネルギー集中との関係}

入力する外力の方向がどの振動子も同じにして空間的な コヒーレントが存在した場合における大振動子(E), 特殊振 動子(E1)および他の小振動子(E2〜E5)を代表する 4 つの工 ネルギーの変化を Fig. 2 に示す. その結果, 特殊振動子に 対して他の小振動子のエネルギーは極端に小さくなってい た. 振動子全体のエネルギーとの比をとったところ (Fig. 3) エネルギーのほとんどが特殊振動子に集中していた. 特殊 振動子に集中したエネルギーは発電によって使われるため, 
振動子全体から特殊振動子にエネルギー流れが存在してい ることが分かった。

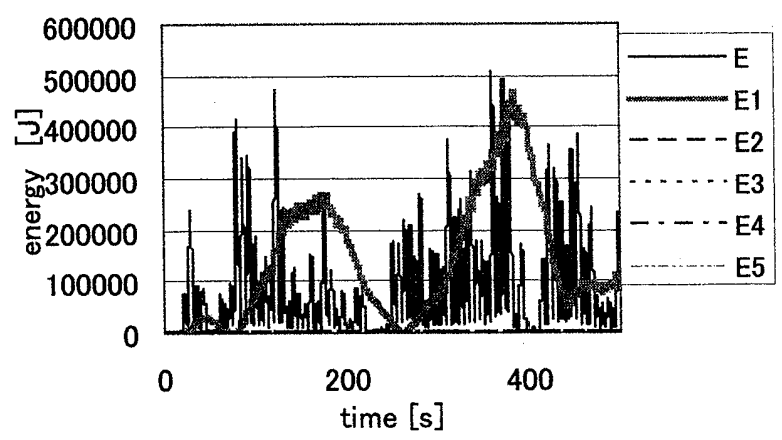

Fig. 2 コヒーレントな入力下での振動子のエネルギーの時間 変化

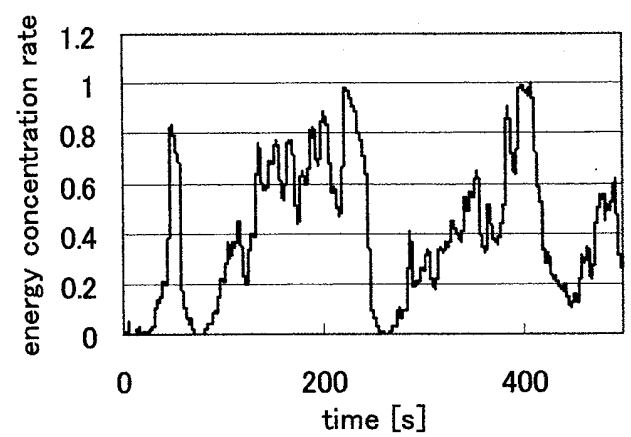

Fig. 3 空間的にコヒーレントな入力下での特殊振動子人 のエネルギー集中率

一方, 各小振動子に対する風による外力が, 時刻, 方向, 大きさ，全てについてランダムであった場合，Fig. 4，5に 示すように，集中率は最大でも約 0.008 であり，特殊振動 子にはエネルギーは集中しなかった。

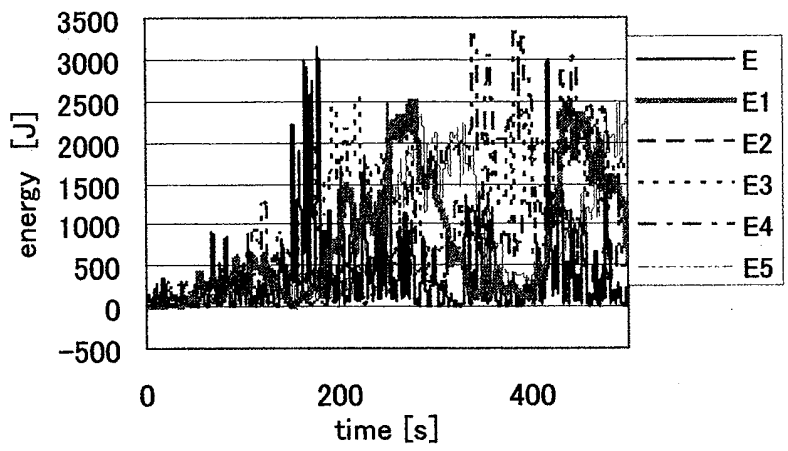

Fig. 4 空間的にランダムな入力下での振動子のエネルギーの 時間変化

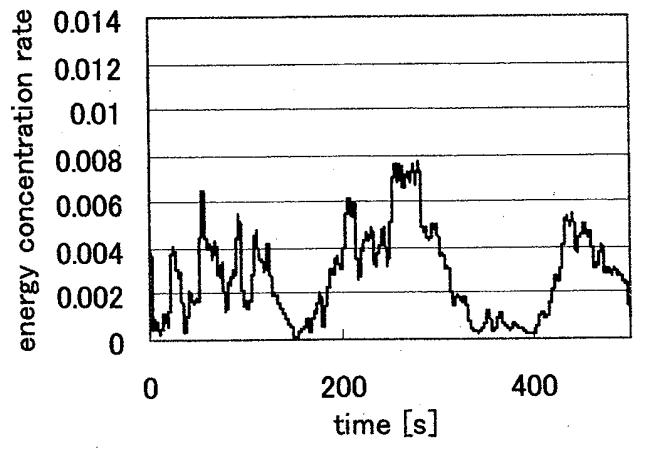

Fig. 5 空間的にランダムな入力下での特殊振動子へのエネル ギー集中率

3-3 波動のコヒーレンスと Deutsche-Jozsa アルゴリズム

波動のコヒーレンスがエネルギーの集中に影響を及ぼす 原因としては，以下に説明する Deutsche-Jozsa 波動アルゴリ ズム[5]と同じ機構が存在するものと考えられる.つまり入 力が空間的にコヒーレントである場合は，各小振動子にお ける振動の位相差は小さく保たれるため, これらが大振動 子との間で交換するエネルギーは大きくなり，大振動子を 介して特殊振動子にエネルギーが集中寸る. 一方、外力の 方向が空間的にランダムであった場合，各小振動子の振動 の位相はバラバラになるため，大振動子との間でエネルギ 一の交換は極端に少なくなり，ここから特殊振動子に流れ るエネルギーも小さくなる.

以上のように、空間的にコヒーレントを持つ風による外 力は, Deutsche-Jozsa アルゴリズムの機構により, Grover アルゴリズムを実現する振動子全体に与えたエネルギーの 大部分を特殊振動子に集中させることができ，これにより 効率良く発電を行うことが可能であることが予測できた.

これらの機構は波動アルゴリズムとして, 解析的にも説 明可能であり，こうした振動現象に現れる特異な性質ばか りでなく，他の波動現象にも有効と考えられる.

\section{参考文献}

[1] L.K. Grover and A.M.Sengupta, A Classical Analog of Quantum Search, quant-ph/0109123 (2001).

[2] 小竹茂夫, 日本機械学会誌, 111,152-153 (2008).

[3] 菊池弘一他、日本機械学会東海支部総会講演会講演 論文集, 2005(54),39-40 (2005).

[4] A.D. Patel, Wave Algorithms : Optimal Database Search and Catalysis, quant-ph/0609042 (2006).

[5] D. Deutsch and R. Jozsa, Proc. R. Soc. London, Ser. A, 439, 553 (1992). 